\title{
Selection of Suitable Urban Agricultural Practice for Indian Cities: a Sustainable Method for City Planners
}

\author{
Athul V. S., N. Lakshmi Thilagam
}

\begin{abstract}
Urban agriculture has become a topic of discussion for the last twenty years, due to the alarming increase in the rate of migration from rural sector to urban areas. Urban population in Indian cities is growing very fast and proper urban agricultural policies are essential to face the scenario. In the Indian context, it becomes more complex as the terms urban culture and agriculture seem mutually exclusive in their fundamental definition of activities and appearance.

The step-by-step procedure of the selection of suitable urban farming practices among; Open land Agriculture (OLA) and Building integrated Agriculture (BIA) is explained. Through case studies of successfully running urban agricultural practices, the influencing parameters on selection of suitable land for OLA are identified. It is a goal-based paper on 'achieving food security from within the city' by promoting urban agricultural activities through emphasising the contribution of OLA to food security. The process involving representation of land in density tower, grading of land, and calculation of yielding capacity of OLA and its share in food security is explained.
\end{abstract}

Keywords: Building integrated agriculture (BIA), Food security, Indian cities, Land suitability parameters, Open land agriculture (OLA), Urban agriculture.

\section{INTRODUCTION}

Urban agriculture has become a subject of discussion among city planners and visionaries due to the alarming increase in the rate of migration from rural sector to urban areas. Indian cities are increasingly emerging as a place of promise for people from the countryside who flock there for opportunities in skilled jobs, modern lifestyle, and a dream of a better tomorrow.

This scenario props up a simple question that has very complex undertones: How to ensure food security in a city for its inhabitants? In simple words, how to feed the city dwellers effectively?

The World Food Summit in 1996 defines food security as when all people, at all times, have physical and economic access to sufficient, safe and nutritious food to meet their dietary needs and food preferences for an active and healthy life [1]. It declares the significance of providing quality food in sufficient quantity to the people. This is when Urban

Revised Manuscript Received on December 05, 2019.

* Correspondence Author

Athul. V. S.*, Research scholar, Kalasalingam School of Architecture, Kalasalingam Academy of Research and Education, Tamil Nadu, India. Email: ar.atulnair@gmail.com

Dr. N. Lakshmi Thilagam, Director \& Professor, Kalasalingam School of Architecture, Kalasalingam Academy of Research and Education, Tamil Nadu, India. Email: hodbarch@klu.ac.in
Agriculture (UA) could help grow crops and be an answer to food security of emerging cities [2]. United Nations Development Programme (UNDP-1996) defines urban agriculture as "An activity that produces, processes, and markets food and other products, on land and water in urban and peri-urban areas, applying intensive production methods, and (re) using natural resources and urban wastes, to yield a diversity of crops and livestock" [1].

The Government of India had come up with many programmes and proposals at the national level to ensure food security in cities, but initiatives to meet that goal through Urban Agriculture is not in progress [3]. The sufficient quantity of food for the city can be delivered from the rural sector but in many ways, the quality is compromised because of the lack of control from governmental side to the areas where the food is produced. Considering these hiccups, UA seems to be an effective way of producing quality food for a city [4].

\section{CALL FOR URBAN AGRICULTURE IN INDIA}

The following reasons demand urban agriculture, a priority for emerging Indian cities.

1. Quality of food produced in rural sector

Currently, most of the Indian cities rely on rural agriculture, either on inter-State farms (The rural farm is situated within the State region of the city) or intra-State farms (The rural farm of a different State region). In both cases, city authorities have less control over the quality of the agriculture products supplied to the city. In a city, the food has to travel miles to reach to the consumers; pesticides are extensively used to keep it fresh. It causes serious health issues for city dwellers.

2. Rapid rise in urban population

The urban population of India has shown a rapid rise, and as per the report of the United Nations, by 2050 more than 50 $\%$ of the Indian population is speculated to live in cities, and Delhi will be the highest populated city in the world [5]. In future, the rural sector may not be able to cater to the increased population effectively with quality food in sufficient quantity.

Urban farming, one of the globally sought-after solutions for the food demand of a city, reduces the physical gap between production and consumption of agricultural goods and thereby ensures its quality and quantity.

For the last few years, many metropolitan Indian cities have shown great interest in the concept of urban farming. 
Many residential units in the city of Mumbai have converted their terraces and balconies, into vegetable cultivation areas. Non-Governmental Organizations are volunteering to encourage people to cultivate fresh and organically grown vegetables in unused open spaces. In Chennai, roof-top farming is gearing up by the introduction of "Do-it-Yourself" kit under the Urban Horticulture Development Scheme in 2014 [4].

In Delhi, widespread agricultural activities are occurring on the banks of River Yamuna. But most of them are unauthorized and hence not reliable. Kerala, one among the rapidly urbanising state in India, is facing a serious issue with the presence of high level of pesticides in fruits and vegetables supplied from neighbouring states. In order to meet the crisis, the government of Kerala has introduced roof-top grow bag cultivation to the major cities of the state [4]. Even though the city dwellers greeted the plan with great enthusiasm, it did not turn out well as expected. People had shown less interest to continue the farming activities after the first reaping. It is observed that incorporating UA to an innate urban community is a hard task that, the people have to accept it and practice it. For them, the terms urban-culture and agriculture seem mutually exclusive in their fundamental definition of activities and appearance. Policy guidance and design concepts in UA have to be developed by considering the attitude of the people. A sense of urgency should be felt with UA as a manner to improve urban lifestyle, and hence it should be integrated with other urban activities such as parks, community gardens, etc.

Urban agriculture is directly connected to the ecological, economic and social system of the city and hence it provides an opportunity to develop a sustainable agricultural policy for the city planners [6]. The selection of suitable space and methods for urban agriculture is very important in terms of sustainable development. The space for UA is not created but borrowed from spaces with other urban activities. With the help of different mapping tools, the planners can locate hidden spaces, a lost space, mixed-used space, or the space around and over the buildings.

In general, urban authorities endorse two types of urban agricultural practices: Open land agriculture (OLA), and Building integrated agriculture (BIA). It is noticed that the failure of UA in few cities was due to the wrong choices with regard to OLA and BIA. The selection between them is a tough task indeed.

The objective of this paper is to introduce, step by step procedure in the selection of suitable urban agricultural practices between OLA and BIA. Instead of analysing the suitability aspects of OLA and BIA simultaneously, the conducive factors of OLA is analysed at first. If it does not have enough potential, then BIA is suggested. It is a goal-based paper on 'achieving food security from within the city' by emphasising the contribution of OLA to food security.

This study is limited to the cultivation of edible plants in urban agriculture, and animal husbandry is not included. Since this article aims at introducing the procedure in selection between OLA and BIA; the details of crops, farming techniques, etc, are excluded. Buildings that are exclusively made for the purpose of Urban agriculture is not taken into account, as it is not economically viable for emerging Indian cities. This paper is prepared through literature reviews, and no testing is conducted.

Even though UA is an essential part of the sustainable cities, it is not free from issues. The problems regarding the availability of land, water resources, and pollution from agricultural activities, etc, have to be taken care of.

\section{OPEN LAND AGRICULTURE (OLA)}

Open land Agriculture is an efficient way of doing urban agriculture on vacant lands in a city through state-of-the-art agricultural methods with the help of interested individuals, institutions, communities, or voluntary organisations. Nowadays it is gaining momentum as a method of converting degraded vacant lands to productive landscapes; thereby increasing the availability of fresh agricultural products and a visual treat to the location. The farming process involves finding suitable open lands and adopting proper farming methods for maximum yielding without disturbing the neighbouring urban activities. The success of OLA is not only depended on the yielding capacity, but its coexistence with urban lifestyle.

Open land agriculture in an urban area has environmental, economic and socio-cultural advantages. It directly improves the microclimate of the region. It is economically more efficient as it requires less infrastructure and technological skills to carry out. Urban food production activities would create a visible transformation in people's quality of life by improving their physical and mental health. It provides a space for people to come together for a good cause and develop a strong community bonding. Activities like farming in a vacant plot would help to stop trash dumping and illegal activities that may otherwise occur in it [7]. Productive gardening on vacant lots can offer regular job opportunities to migrant people who were practicing agriculture in rural areas, and lend a more positive image of urban neighbourhoods. Since farming is done in open land and visible to people the quality of the agricultural products can be ensured [7]. Proper planning of OLA provides a visual identity and sustainable outlook to the city.

\section{BUILDING INTEGRATED AGRICULTURE (BIA)}

Building integrated agriculture (BIA) combines agriscape with humanscape and buildscape. It is the practice of placing high-performance agriculture systems, around, over or inside buildings (Building integrated agriculture was termed by Dr.Ted Caplow in 2007) [8]. The speciality of this kind of farming is that, it goes well with other activities of the building and does not need an independent open space. It is more advisable in cities with less open land for cultivation.

Depending on the part of the building where the farming is planned, BIA is divided into three categories; indoor farms, rooftop farms and edible green walls. Among these, rooftop agriculture is widely used as it is easy to set off and maintain [9]. BIA is an alternate option to gain food security, where suitable open land is not available enough for agricultural production. But it is more expensive than Open land agriculture as it requires additional technical solutions to bring water,

Blue Eyes Intelligence Engineering 
electricity, and provision for waste disposal [9] Community participation and visual treat of the space is less in BIA than OLA.

\section{THE PARAMETERS FOR THE SELECTION OF SUITABLE LAND FOR OPEN LAND AGRICULTURE}

In order to understand the ability aspects of urban agriculture on open land and the implication on city planning, the literature study of the city of Havana in Cuba, Community gardens of London and Metropolitan Jakarta are conducted and the influencing parameters are tabulated.

Table- I: Grading of influencing parameters for productive UA

Source: Author

\begin{tabular}{|c|c|c|c|c|c|}
\hline & PARAMETERS & HAVANA & LONDON & JAKARTA & GRADING \\
\hline $\mathrm{I}$ & \multicolumn{5}{|l|}{ CITY LEVEL } \\
\hline 1(a) & $\begin{array}{l}\text { LOCATION: CONTINUOUS LAND, } \\
\text { AWAY FROM CITY CENTER (OR) }\end{array}$ & $\mathrm{XXX}$ & $\mathrm{XXX}$ & $\mathrm{x}$ & A- \\
\hline (b) & $\begin{array}{l}\text { LOCATION: CONTINUOUS LAND, } \\
\text { NEAR TO CITY CENTER (OR) }\end{array}$ & $\mathrm{x}$ & $\mathrm{x}$ & $\mathrm{XXX}$ & $\mathrm{C}+$ \\
\hline (c) & $\begin{array}{l}\text { LOCATION: FRAGMENTED LAND, } \\
\text { AWAY FROM CITY CENTER (OR) }\end{array}$ & $\mathrm{x}$ & $\mathrm{xX}$ & $\mathrm{x}$ & C \\
\hline (d) & $\begin{array}{l}\text { LOCATION: FRAGMENTED LAND, } \\
\text { NEAR TO CITY CENTER }\end{array}$ & $\mathrm{xxx}$ & $\mathrm{x}$ & $\mathrm{xxx}$ & A- \\
\hline 2 & SCOPE OF VISUAL TREAT & $\mathrm{xx}$ & $\mathrm{x}$ & $\mathrm{xx}$ & B- \\
\hline II & \multicolumn{5}{|l|}{ SITE LEVEL } \\
\hline 3 & $\begin{array}{l}\text { SIZE, SHAPE AND GRADE OF } \\
\text { LAND }\end{array}$ & $\mathrm{x}$ & $\mathrm{x}$ & $\mathrm{xX}$ & C \\
\hline 4 & FRESH LAND & $\mathrm{x}$ & $\mathrm{x}$ & $\mathrm{x}$ & C- \\
\hline 5 & $\begin{array}{l}\text { PROVISON FOR } \\
\text { INFRASTRUCTURE: WATER, } \\
\text { ELECTRICITY, TRANSPORTATION }\end{array}$ & $\mathrm{XXX}$ & $\mathrm{XXX}$ & $\mathrm{XX}$ & A \\
\hline 6 & $\begin{array}{l}\text { SAFE LAND FOR CULTIVATION } \\
\text { (INTERRUPTION BY LOCAL } \\
\text { PEOPLE) }\end{array}$ & $\mathrm{XX}$ & $\mathrm{XXX}$ & $\mathrm{xx}$ & $\mathrm{B}+$ \\
\hline 7 & $\begin{array}{l}\text { AVAILABILITY OF LAND FOR } \\
\text { LONGTERM, UA-PRACTICE }\end{array}$ & $\mathrm{XXX}$ & $\mathrm{XXX}$ & $\mathrm{xXX}$ & $\mathrm{A}^{+}$ \\
\hline
\end{tabular}

\begin{tabular}{|c|c|c|c|c|c|}
\hline \multirow[t]{2}{*}{ III } & \multicolumn{5}{|c|}{ HUMAN LEVEL: FARMER CATEGORY } \\
\hline & $\begin{array}{l}\text { VOLUNTARY WORKERS OF } \\
\text { INSTITUTIONS (AND, OR) }\end{array}$ & $\mathrm{XX}$ & $\mathrm{XXX}$ & $\mathrm{XXX}$ & A \\
\hline (b) & $\begin{array}{l}\text { FAMILY RUN CULTIVATION } \\
\text { (AND, OR) }\end{array}$ & $\mathrm{xXX}$ & $\mathrm{XXX}$ & $\mathrm{xx}$ & A \\
\hline (c) & $\begin{array}{l}\text { CO-OPERATIVE GROUPS } \\
\text { (AND, OR) }\end{array}$ & $\mathrm{XXX}$ & $\mathrm{XXX}$ & $\mathrm{XXX}$ & $\mathrm{A}^{+}$ \\
\hline (d) & $\begin{array}{l}\text { SMALL SCALE ENTREPRENEUR } \\
\text { (AND, OR) }\end{array}$ & $\mathrm{XXX}$ & $\mathrm{XXX}$ & $\mathrm{XXX}$ & $\mathrm{A}+$ \\
\hline (e) & LARGE SCALE ENTREPRENEUR & $\mathrm{XXX}$ & $\mathrm{XX}$ & $\mathrm{XXX}$ & A \\
\hline & CHARACTER OF THE LAND & \multicolumn{4}{|c|}{ INFLUENCE ON SUCCESS RATE } \\
\hline & XXX- HIGHLY SIGNIFICANT & $\mathrm{A}, \mathrm{A}+, \mathrm{A}-$ & \multicolumn{3}{|c|}{ FLUENTIAL } \\
\hline & XX- MODERATELY SIGNIFICANT & B,B+,B- & \multicolumn{3}{|c|}{$\begin{array}{l}\text { MODERATELY } \\
\text { INFLUENTIAL }\end{array}$} \\
\hline & $\mathrm{X}$ - LESS SIGNIFICANT & $\mathrm{C}, \mathrm{C}+\mathrm{C}-$ & \multicolumn{3}{|c|}{ LESS INFLUENTIAL } \\
\hline
\end{tabular}

GRADING CRITERIA

$\mathrm{XXX}, \mathrm{XXX}, \mathrm{XXX}[\mathrm{A}+] / \mathrm{XXX}, \mathrm{XXX}, \mathrm{XX}[\mathrm{A}] / \mathrm{XXX}, \mathrm{XXX}, \mathrm{X}[\mathrm{A}-]$

$\mathrm{XX}, \mathrm{XX}, \mathrm{XXX}[\mathrm{B}+] / \mathrm{XX}, \mathrm{XX}, \mathrm{XX}[\mathrm{B}] / \mathrm{XX}, \mathrm{XX}, \mathrm{X}[\mathrm{B}-]$

$\mathrm{X}, \mathrm{X}, \mathrm{XXX}[\mathrm{C}+] / \mathrm{X}, \mathrm{X}, \mathrm{XX}[\mathrm{C}] / \mathrm{X}, \mathrm{X}, \mathrm{X}[\mathrm{C}-]$
The case cities were selected on the basis of the successful practice of urban agriculture in open land and their representation to different geographic locations. The study is conducted with the intention of developing internationally relevant conclusions on land use that support urban agriculture. Regional factors like climate, soil type, crop types, farming methods, etc. are not discussed here as they are irrelevant in generalizing the facts.

The parameters are extracted from three levels such as,

- The City level

- The Site level

- The Human level.

\section{A. Urban agriculture: Havana, Cuba.}

Cuban agricultural model is globally admired and is quoted as a successful example of the response to the most urgent challenge of our time, -Hunger and Environmental degradation. During the period of 1960 and till 1989, Cuba dedicated its agricultural land on monocrop sugarcane cultivation and was exported to Soviet Union and imported major part of their daily food in return [10]. After the fall of Soviet Union in 1989 Cuban economic system crushed as Soviets were their most trusted buyers of sugarcane. This led them to face severe shortage of food, and soon they realised the significance of self-sufficiency in food production and switched over to it. The urban agricultural movement in Cuba was a crisis-induced strategy. The characteristic of Cuban urban agriculture is self-sufficiency, which is justified by the cyclic connection of farmer, crops, market, and consumer [11]. The absolute help from government side, the advice from institutions and research organisations and most importantly willingness of the people to overcome the worst situations they faced; turned out to be a successful agricultural model. In the city of Havana, about $90 \%$ of vegetables and fruits are produced within the city [12].

- City level:

In Havana, the urban agriculture sites are distributed along the urban fringe and the major roads that lead to the city centre. Derelict vacant lands are converted to agricultural land in the city centre, which is quite small and not more than the footprint of a single building. Moving out from the centre, large urban agricultural sites are found often adjacent to industrial areas or newly developed residential settlements. The community gardens are turned to be intensive cultivation gardens with a common design guide. Within that, the changing crop patterns, with respect to seasons, is visually appealing and gives an identity to the city [12].

- Site level:

The agricultural sites are determined by the location and type of agricultural activity. The cultivation is mass production and organic in nature. Open selling outlets are seen near large urban farms. The sites are surrounded by roads and secured with fencing but without blocking the view of farming activities to the pedestrians. Efficient irrigation systems are installed in sites to face water scarcity problem [13]. Site characters like slope, elevation, shape, etc were never a constraint for Cuban agricultural practice.

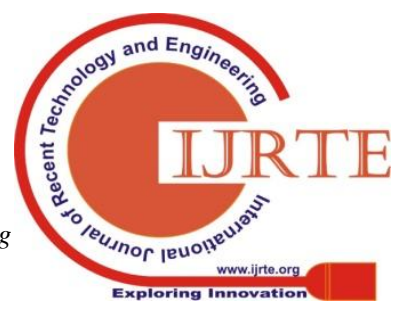


The Cuban signature farming model 'Organopónicos' is a high-yield cultivation system that gives an opportunity to cultivate almost everywhere, irrespective of the land and the soil condition [14].

- Human level:

The farmlands are managed by various groups of farmers at multiple levels according to the size of the land. The farming ranges from voluntary cultivation by workers, one person or family-run small scale activity or large-scale activity by entrepreneurs or a community or cooperatives. Urban leisure activates are performed around large agricultural farms. The folds of the site boundaries are used as space for community gatherings. For Cubans, agriculture activity is one of the major urban functions and does not feel like something that fused to the urban fabric [12].

\section{B. The community gardens of London, UK}

The food requirement of London is growing up and requires large productive land tracts in order to sustain itself. In 1997, the city of Bath had just one farmers' market and by 2018, there has been a tremendous increase to more than 800 [15]. The urban farming in London is based on certain social aspects like the anxiety of fast urbanization, less availability of productive land, and health issues of a large population that is physically inactive and consumes more packaged food. There is also an urge among them to be a part of a global sustainable movement of practicing agriculture [16].

- City level:

The land allocation pattern in London is that the large farmlands are made available in the outer part of the city. In this continuous farmlands, the local authorities allot multiple sites for farmers. Private gardens, smaller plots near housing estates, etc are also taken up for agriculture. The implementation of community garden shows steady growth in city centers, not only increase the food production but enhance the visual appearance of the region as well. These spaces attract public as recreational gathering space [16].

- Site level:

Modern agricultural methods are widely used to increase production and to reduce environmental impact. Sufficient water and electricity are made available by the authority to support farming activities. The markets for the urban produce are not well established, but the products from the region are bought by supermarkets that play a major role in distributing them as retail.

- Human level:

About $6 \%$ of the property holders are less than 35 years of age, which shows the interest of youngsters in agriculture. About 2.8 million houses have private spaces for gardening that account for about $20 \%$ of the total area of the city. The productive gardens are funded by the government authorities, NGOs or voluntarily by the community members. As it is community involved farming method, individuals from all walks of life take part in the activity merrily. Few farms have provided space for students to actively involved in farming and thus the budding generation is being attracted to agriculture [16].

\section{Urban agriculture: Jakarta, Indonesia}

Jakarta, the largest and the most populated city in Indonesia, faced a food crisis during 1998. The economical imbalance and non-availability of regular income to the people of economically weaker sections led to leasing out of vacant land for cultivation. The agricultural activists of Jakarta supported this movement by renting the land from owners for collective farming. The government aided these activities through many schemes boosting the urban farming movement in the city [17].

- City level:

Jakarta does not follow any particular pattern in agriculture and the land is unevenly distributed as patches. Urban agriculture is practiced along government-owned vacant land, riverside, roadside, and also in diverse environments including coastal, industrial, and residential areas. It is observed that rapid urbanization is still going on and results in the fragmentation of farmlands [18].The lack of effective synchronization between land use planning policies and agricultural policies is evident and that intensifies the fragmentation of farmlands [17].

- Site level:

The region has a deep running network of water canals and rivers that has the potential to provide sufficient irrigation. A large area of low lying, flat land with fertile alluvial soil makes farming favorable. The agricultural lands are made easily accessible by means of effective road, rail and water transport systems. Electricity and irrigation systems are well capable of meeting the requirements of farming activities [19]. The farming along with public places such as roadsides, riversides, etc, gives an impression of agriculture as part of urban infrastructure.

- Human level:

The majority of the farmers are rural migrants and the initiative from government side to generate employment opportunities is remarkable. But still the migrant farmers stay near the urban agricultural land in temporary houses, and leave the place when the owner decides to stop the agricultural activities making it a nonreliable income generating job.

Table- I. shows the influencing parameters for running productive agricultural farms, with three levels of grading such as City level, Site level, and Human level.

\section{THE DECISION MAKING PROCESS}

The decision making strategy in the selection, between OLA and BIA is explained through step by step procedure starting from general categorization of land to the calculation of the total yielding capacity of the city. The basic idea is to select and grade the suitable land by analysing the available land with respect to certain urban parameters that support maximum yielding. This is in the backdrop of a few factors that are conflicting and qualitative in nature and are explicitly evaluated and ranked. The total yielding capacity of the city is then compared with food security and the difference is assumed to be compensated with Building Integrated Agriculture. The steps involved in the process are illustrated in Fig.1. 


\section{A. Formation of Density tower}

The density tower experiments are conducted in physics to understand the idea of the density of different liquids. The density tower is formed by a combination of different liquids, which gets layered one on top of the other, depending on their densities. The liquid with low density will go to the top and the high density will move to the bottom of the tower.

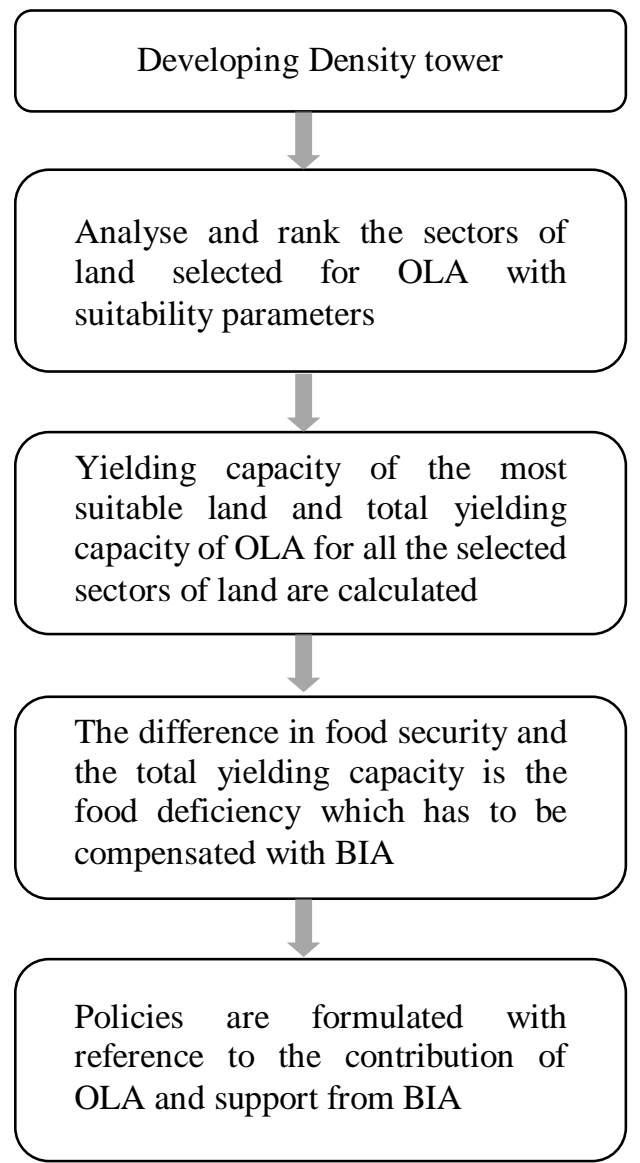

Fig. 1. Decision making process Source: Author

In this case, the Built-up area density map of the city is made according to building footprint on the land, and is diagrammatically arranged in the order of land with high density of built-up area in the bottom and low density at the top.

The illustration of developing the Density tower is shown in Fig.2. In the built-up area map, the dark portions represent high density built-up area (A, B, C...) and lighter shades represent the low density built-up area or vacant land. When they are arranged in density tower, the area of the bands in the tower and the corresponding portion in the map is kept the same. The topmost portion of the density tower representing the most vacant land is assumed as a high scope area for OLA and the bottom space representing high density built-up land is assumed as the area with more scope for BIA. In practice, any land mapping tool can be used to prepare the built-up area density map.

The advantage of representing land in the density tower is that it gives an instant idea of scope to development of OLA or BIA for a particular city in accordance with existing land use. The character of the density tower is that different layers do not mix, and they float one on top of the other. It will be easy to understand the position of a particular land, with respect to built-up area density and its up-and-down movement in the density tower when the building footprint of that layer is changed by introducing policies and plans. This can be visualised through the help of simulation software.

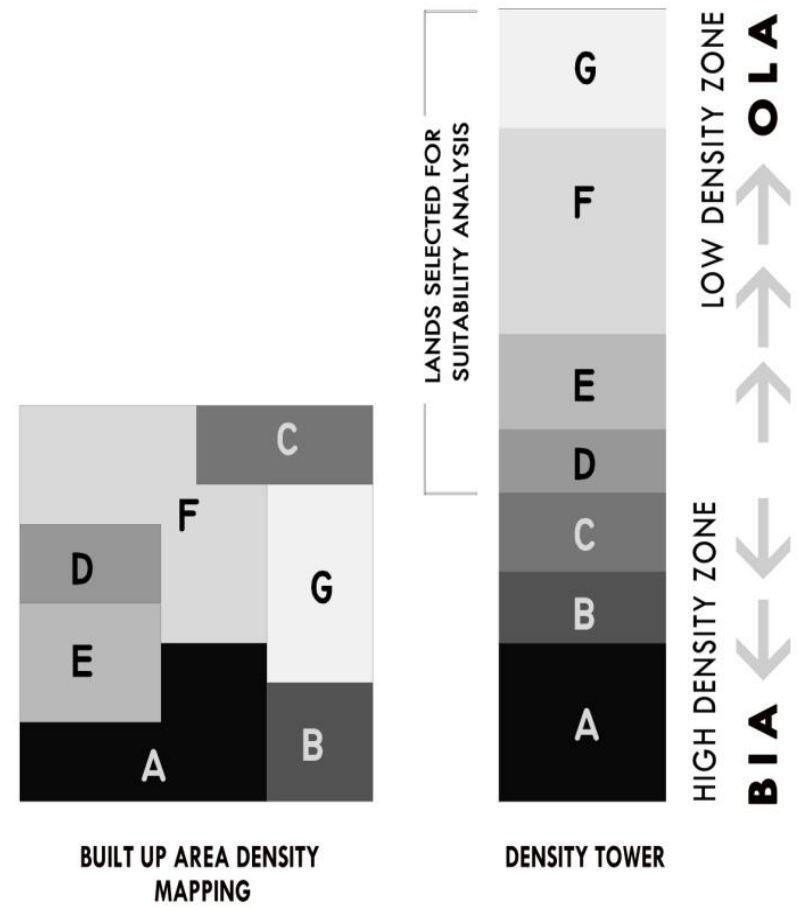

Fig. 2. Developing Density tower

Source: Author

\section{B. Identification, Suitability analysis, Grading and Ranking of land}

The principal purpose of land suitability analysis is to identify the high potential land for cultivation [20]. In the case of urban farming, many aspects other than what is usually analysed in rural farming are considered.

This is a crucial step to identify the influencing parameters for developing a successful urban agricultural plan. These are studied at different levels, may help to identify the most suitable land for Open land agriculture. The areas that lie at the top region of a density tower are selected for suitability analysis and grading. Food and Agriculture Organization (FAO) of the United Nations classifies land in an area according to suitability for farming as "Highly suitable (S1), moderately suitable (S2), marginally suitable (S3), currently not-suitable (N1) and permanently not-suitable (N2)" [21]. The same classification system is also used here, but without identifying $\mathrm{N} 1$ and N2.

The ranking of the land ( $\mathrm{S} 1, \mathrm{~S} 2$, and $\mathrm{S} 3$ ) for OLA is done from the grading of influencing parameter as shown in Table 1. It is to be noted that in Fig.2 the land ' $G$ ' may be the most vacant land but may not fall under highly suitable land category $(\mathrm{S} 1)$. 
The land-S1 holds the maximum ranking weightage that is 1, subsequently followed by Land S2, S3 with lesser weightage.

\section{Specimen study to find out the yielding capacity of highly suitable land (Land-S1)}

Specimen study is conducted to find out the yielding capacity of the highly suitable land (Land-S1), with the help of agricultural experts. A portion of land from Land-S1 is selected as a convenient sample for specimen studies, and the most suitable farming methods and crops are chosen to achieve maximum yielding.

The yielding capacity of land-S1 is calculated as,

$$
\mathrm{Y}_{\mathrm{S} 1}=\mathrm{A}_{\mathrm{S} 1} \times \mathrm{R}_{\mathrm{S} 1} \times \mathrm{y}
$$

$\mathrm{A}_{\mathrm{S} 1}$ - Area of the highly suitable Land -S1

$\mathrm{R}_{\mathrm{S} 1}$ - Ranking weightage of highly suitable land S1 and the value is assumed as 1 .

$\mathrm{y}$-Yielding capacity of the specimen per unit area.

\section{Calculation of total yielding capacity from urban open land agriculture}

The yielding capacity of each section of land selected for analysis in density tower is calculated by multiplying the respective Ranking weightage (ref: Table 1) with yielding capacity of the specimen sample, and area of the particular sector. The total Yielding capacity of the city from Open land agriculture will be the sum of the yielding capacity of all the sections selected for the study.

Total yielding capacity $=\sum_{i=1}^{3} A_{S i} \times R_{S i} \times y$

$\mathrm{A}_{\mathrm{Si}}$-Area of land corresponds to $\mathrm{S} 1, \mathrm{~S} 2, \mathrm{~S} 3(\mathrm{i}=1,2,3)$,

$\mathrm{R}_{\mathrm{Si}}$ - The Corresponding ranking weightage.

$\mathrm{y}$-Yielding capacity of the sample per unit area.

\section{DISCUSSION}

By studying the three cases of OLA, the following parameters are found to be relevant to choose the suitable land for effective UA (Table I)

City level: While considering yielding capacity, continuity of land near the city centre is not an influential factor, rather it may be difficult to identify such a long stretch of land. The continuous stretch of land away from the city centre is more advisable, whereas patches of the land near to the city centre may give more visual treat to the commuters.

Site level: The availability of land for long-term agriculture is an important criterion. The selection of suitable land depends on the city growth rate and existing land use guidelines. Availability of infrastructure such as road access, water, electricity, etc, is major concern. Size, shape, and grade do not influence the UA much, which is proven in 'Organopónicos' -the Cuban agricultural model. Security and vandalism of the farm is not a concern for the selection of land, as it can be dealt with modern security measures and making aware of the community about the importance of UA in a city.

The Human level: As far as yielding capacity is concerned,
UA on a large scale is most preferred on the outskirts of the city. NGOs, and cooperative groups could develop agricultural parks inside the city, and individuals and families could cultivate on patches near to city centers. This will spread a new culture of harmonious synchronisation of agriculture into urban lifestyle.

In a city, open land refers to both public and private open land. When a policy is formulated, public and private lands have to be treated as separate. Transformation of public land and private land as agricultural land requires separate guidelines and rules, especially freezing the land for a particular period. OLA is very much advisable in Indian cities with majority of open land under the ownership of the local authority or government institutions. Practicing open land agriculture on public land will gradually alert the people about the importance of agriculture in daily life and inculcate a culture of practicing farming effectively at their residence.

The planning strategy on urban agriculture for a city is based on food deficiency, which is the difference in food security and yielding capacity from Open Land Agriculture and Building Integrated Agriculture. However, BIA is considered as a supporting factor to meet the deficiency arising out of OLA.

Food deficiency $=($ Food security $)-($ Total yielding capacity from OLA)

The difference in food security and yielding capacity of Open Land Agriculture is the deficit to meet the goal of 'achieving food security from within the city'. It could be compensated by promoting Building integrated agriculture (BIA).

The study concentrates on the need for selection of Open Land Agriculture over Building Integrated Agriculture through density tower and grading of supporting parameters. Even if the city could achieve food security through Open Land Agriculture, Building Integrated Agriculture should not be neglected completely. Further studies may be conducted to evaluate the role of BIA with respect to the growth pattern of the city. Prospect of further studies are evident in suitability ranking of BIA in a city profile.

Sustainable development goals (SDG-11) of United Nations proposals, clearly states the importance of providing public spaces in an urban area. Further studies are required to prove how these spaces could be used productively through urban agriculture [22].

\section{CONCLUSION}

This paper gives a vision to the planners and generates backup data for the formulation of plans and policies related to urban agriculture. The case studies of successfully running UA practices around the world show that Indian cities have high potential for food security, through sustainable agricultural practice. The step-by-step procedure explains the calculation of the maximum yielding capacity of Open land agriculture (OLA) for a given city. It also puts light on the contribution of OLA to food security.

The procedure seems to be more effective than the usual trial and error method or the blind acceptance of what others are doing.

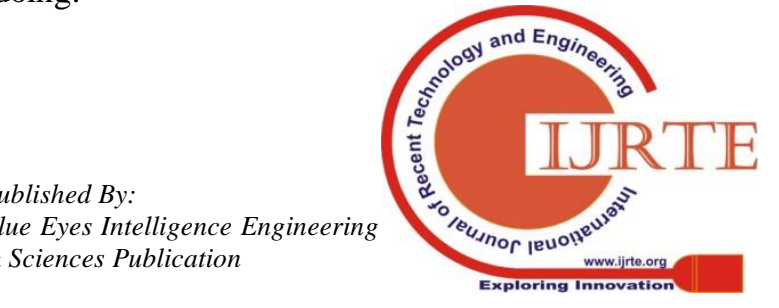


It gives an authentic supporting data from which the growth pattern of a city could be controlled. It is a goal-based method on 'the food security from within the city'. It is observed that by promoting OLA, the urban congestion could be reduced and city gets more breathing space. It also helps the city dwellers to accept agriculture as part of their lifestyle and inculcate the habit of nurturing self sufficient food.

It may not be possible to grow all types of agricultural products inside the city and hence $100 \%$ of food security is not possible. But it could surely be an answer to food sovereignty. It could give option to people to choose staple crops that can be cultivated regionally to meet the demand.

\section{REFERENCES}

1. Food and Agriculture Organization (November 1996). "Rome Declaration on Food Security and World Food Summit Plan of Action".[Online]Available:http://www.fao.org/3/w3613e/w3613e00.ht m (Accessed June 01, 2019), November 1996.

2. Bailkey, M., and J. Nasr. 2000. "From Brownfields to Greenfields: Producing Food in North American Cities," Community Food Security News. Fall 1999/Winter 2000, 2000.

3. S.Dipak, C.Arun "Farms in cities,A case for urban agriculture in India”Down to Earth [Online]

Available:https://www.downtoearth.org.in/blog/farms-in-cities-35682 (Accessed June 01, 2019), 2018.

4. Meera Sahasranaman, "Future of urban agriculture in India", IRAP Occasional Paper, No. 10-1216, December, 2016.

5. "World Urbanization Prospects 2018", United Nations DESA / Population Division [Online] Available: https://population.un.org/wup/ (Accessed June 01, 2019), 2018.

6. Hallett, S., Hoagland, L., \& Toner, E. "Urban Agriculture: Environmental, Economic, and Social Perspectives". In Horticultural Reviews (pp. 65-120). John Wiley \& Sons Inc, 2016.

7. Melissa N. Poulsen, MPH \& Marie L. Spiker "Urban Farms into the Social Landscape of Cities Recommendations for Strengthening the Relationship between Urban Farms and Local Communities", MSPH, RD Johns Hopkins Bloomberg School of Public Health, July 2014.

8. "Building-integrated agriculture", [Online] Available: https://ipfs.io/ipfs/QmXoypizjW3WknFiJnKLwHCnL72vedxjQkDDP1 $\mathrm{mXWo6uco/wiki/Building-integrated \_ agriculture.html} \mathrm{(Accessed} \mathrm{June}$ 01, 2019), 2017.

9. Specht, K., Siebert, R., Hartmann, I., Freisinger, U. B., Sawicka, M., Werner, A,Dierich, A. "Urban agriculture of the future: an overview of sustainability aspects of food production in and on buildings. Agriculture and Human Values", 31(1), pp. 33-51, 2013.

10. "Organic or starve: can Cuba's new farming model provide food security?", The Guardian, International edition [Online]Available:https://www.theguardian.com/environment/2017/oct /28/organic-or-starve-can-cubas-new-farming-model-provide-food-sec urity, (Accessed June 01, 2019), 2017.

11. Novo MG, Murphy C (2000) Urban agriculture in the city of Havana: a popular response to crisis. In: Bakker N, Dubbeling M, Guendel S, Sabel Koschella U, de Zeeuw H (eds) Growing cities, growing food, urban agriculture on the policy agenda. DSE, Feldafing, pp 329-348

12. André Viljoen, Katrin Bohn, Joe Howe, "Continuous productive urban landscapes: designing urban agriculture for sustainable cities," Architectural Press, 2005, pp. 146-190.

13. André Viljoen, Katrin Bohn, "Continuous Productive Urban Landscape (CPUL): Essential infrastructure and edible ornament", Open House International 34(2).

14. FAO (2015) "Urban and Peri-urban Agriculture in Latin America and the Caribbean", Growing greener cities. [Online] Available: http://www.fao.org/ag/agp/greenercities/en/GGCLAC/havana.html (Accessed June 01, 2019), 2015.

15. C. Tornaghi, "Urban Gardening as Politics". Routledge, 2018.

16. Petts.James \& World Health Organization."Urban agriculture in London" Copenhagen : WHO Regional Office for Europe, 2001.

17. Purnomohadi.N "Jakarta: Urban agriculture as an alternative strategy to face the economic crisis" Resource Centre on Urban Agriculture and Forestry, (pp. 467-482), 1999.

18. D. O. Pribadi and S. Pauleit, "The dynamics of peri-urban agriculture during rapid urbanization of Jabodetabek Metropolitan Area," Land Use Policy, vol. 48, pp. 13-24, Nov. 2015

19. G. S. Indraprahasta, "The Potential of Urban Agriculture Development in Jakarta," Procedia Environmental Sciences, vol. 17, pp. 11-19, 2013.
20. H. Kazemi and H. Akinci, "A land use suitability model for rainfed farming by Multi-criteria Decision-making Analysis (MCDA) and Geographic Information System (GIS),” Ecological Engineering, vol. 116, pp. 1-6, Jun. 2018

21. "A framework for land evaluation "Chapter 3: Land suitability classifications, FAO Soils bulletin M-51 ISBN 92-5-100111-1,1981.

22. UN-Habitat, Sustainable Development Goal, Target 11.7 [Online] Available:https://unstats.un.org/sdgs/metadata/files/Metadata-11-07-01. pdf (Accessed June 01, 2019), 2015.

\section{AUTHORS PROFILE}

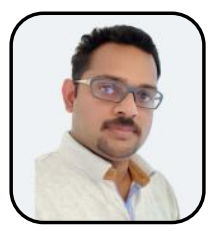

Athul V. S. is an Architect registered to Council of Architecture, India and pursuing $\mathrm{PhD}$ in Architecture from Kalasalingam Academy of Research and Education, (KARE) TamilNadu, India. His research interest is in urban agriculture and City planning. Currently working as the Associate professor, NRM School of Architecture, Kerala, under Cochin University of Science and Technology (CUSAT), Kerala, India. He has been the consultant to various Government organizations, and also associated with many significant architecture and infrastructure development projects in India.

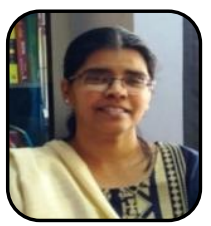

Dr. N. Lakshmi Thilagam is an Architect and Urban Designer and holds a PhD from the Indian Institute of Technology, Kharagpur, India. Her research interests are traditional urbanism, space syntax application for historic cities, heritage and urban conservation. She is currently conducting research to analyze the principles of sustainability exhibited in the traditional urban patterns of the historic cities of Tamil Nadu. As a passionate academician who has been teaching for the last two decades. She also writes on the subject of Architectural education. 